\title{
Intersections between public and private: community gardens, community service and geographies of care in the US City of Buffalo, NY
}

\section{LaDona Knigge, California State University, Chico}

\section{Introduction}

The planting of community gardens in urban areas is a common, community-based strategy for the temporary reuse of vacant lots in declining urban neighborhoods in the United States (HANNA \& OH 2000; Hynes 1996; Lawson 2005; Schmelzkopf 1995, 2002). The garden sites are located in places that are generally not of interest to developers, gentrifiers or the business community; they are in places that struggle to maintain city services and keep their streets safe; in short, they are to be found in marginalized places (KNIGGE 2006). The benefits of community gardens are widely known; they have not only been the focus of civic and beautification programs, but have also been an important source of fresh fruits and vegetables in times of need throughout the history of the United States. In times of economic depression, government supported community gardening programs promoted self-sufficiency and dignity for urban dwellers by enabling them to grow food for their families in subsistence or allotment gardens. Modeled after the British Victory Gardens, the growing of food in community gardens during World Wars I and II promoted conservation, nationalism, and patriotism by conserving gasoline and other resources for use by the military and allies (HyNes 1996; SChMELzKopf 1995, 2002; WARNER 1987). Today, community gardens continue to supply fresh food in urban neighborhoods while serving as spaces of community building, engagement and support.

This paper is part of a larger research project on community gardens in Buffalo, NY, that found a close connection between vacant lot community gardens in marginalized neighborhoods and local efforts to strengthen the community food system and support community food security (KNIGGE 2006). As the research progressed, an important theme emerges: it became apparent that many community gardening organizations were also engaged in the provision of other types of social services and care well beyond those typically associated with community gardening, including after school programs, tutoring, youth services and emergency/refugee services - community social services that have been devolved, reduced or dismantled from government programs in recent years. In light of this finding, the purpose of this paper is to look closer at the interrelatedness of issues of public space, citizenship, gender and race and larger structural processes of deindustrialization, globalization and state restructuring. It documents the possible consequences of a dismantling of the welfare state and the devolution of responsibilities for social welfare to individuals and communities, enabled by both neoliberal and conservative forces. In particular, attention is given to the use of public policy to relocate responsibility for social welfare in the private sphere, locating care in the community (Staeheli 2003: 817). To examine these issues, a feminist and critical perspective of public space, citizenship, community and geographies of care, welfare and responsibility is taken (LAWSON 2007; STAEHELI \& BROWN 2003), albeit coloured by other critiques of public space and neoliberal reforms (BRENNER \& Theodore 2002; LeItNer \& Sheppard 2007).

The first section of the paper describes the research area with a short history of the economic conditions and the development of community gardens in the City of Buffalo and the methods used for this research project. The next section discusses the concepts of public space, citizenship, gender and geographies of care. This discussion is supported by three case studies of community gardens in Buffalo, NY, that are engaged in the provision of an assortment of social and community services. The paper concludes with a summary of the kinds of care and support provided by the community gardening organizations and their importance for individual community members. It situates the work of the community within larger global processes and notes that the effects of larger structural processes, such as deindustrialization, privatization, and state restructuring are clearly felt at the local everyday level of Buffalo's residents. Their lives within the context of social, politi$\mathrm{cal}$ and economic conditions are related to and cannot be separated from the larger global context.

\section{Research area and methods}

\subsection{Economic urban context}

In the current global economy, capital is increasingly mobile, constantly relocating and rebuilding in new territories that offer the greatest return. In order to continue to expand, capital devalues, reworks, junks and renders obsolete the very geographic landscapes that it created (BRENNER \& TheODore 2002). As capital moves in search of higher profits and a willing labor force, cities and communities are left to cope with an eroding tax base, economic and environmental damage caused 
by the abandonment of aging infrastructure, and the loss of jobs and revenue. The economic changes that have occurred within the City of Buffalo over the past eleven decades exemplify this cycle of capital (dis-)investment and uneven development and its economic, social and political implications on urban areas (BRENNER \& THEOdore 2002; SMith \& Williams 1986).

At the turn of the $20^{\text {th }}$ century, Buffalo was the eighth largest city in the United States and host of the 1900 World Exposition; a vibrant, bustling metropolis with a diverse economy based on commerce in commodities, manufacturing, the production of steel, and shipping with modern rail and water transportation systems (LAChiusa 2002; own calculations based on census data 1970, 1980, 1990, 2000, www.census.gov). Now at the beginning of the $21^{\text {st }}$ century, due to financial insolvency, the City of Buffalo is managed by a Control Board and still struggling with the loss of jobs, flight of capital, and maintenance of public sector infrastructure that began in the 1950s with the construction of the interstate highway system and out migration of the middle class into surrounding communities and suburban developments. This cycle of disinvestment accelerated in the late 1970s with the closing of Bethlehem Steel; from employing 20,000 people in its Lackawanna Plant south of Buffalo, the plant reduced its labor force to 8500 in 1977 and finally closed its doors in 1983 (HIsTORY OF Buffalo; MeYer 2005). The devastating effects of the closing of the steel mills exacerbated the current period of economic decline in the region.

Today, a once economically prosperous, industrial city of 580,000 (1950) has a population of approximately 280,000 and faces a fiscal crisis and declining tax base due to the loss of industry and jobs. Since 1970, the City of Buffalo has experienced a $37 \%$ decrease in population, a $27 \%$ increase of families living in poverty, and increased racial segregation leading to a growing number of vacant buildings and/or deteriorating housing stock (own calculations based on census data 1970, 1980, 1990, 2000, www.census.gov). In response to this housing surplus, the City instituted an aggressive housing demolition policy that includes the demolition of 31,000 houses between 1990 and 2010. Even with this aggressive policy, more than $15 \%$ of the structures in the City of Buffalo were vacant in 2003. Of the estimated 12,500 vacant parcels, nearly 4000 are city-owned. In light of declining tax revenues and fiscal constraints, the maintenance thereof is indeed a challenge for the city government (CORNELl COOPERATIVE EXTENSION 2004).

\subsection{Development of community gardens in Buffalo, NY}

Buffalo's community gardens are largely the result of the efforts of J. MiLton ZecKHAUSER, founder of
Grassroots Gardens of Buffalo, a non-profit organization that provides support for community gardening organizations. City policy enacted in the 1990s requires community organizations to obtain five-year leases for the establishment of community gardens on city-owned vacant lots. The leases specifically state that the use as a community garden is contingent and can be terminated at anytime. If an investor wishes to purchase a site for market value, the lease will be terminated. Indeed, due to this policy, the long-term existence or sustainability of these vacant lot community gardens is tenuous and precarious, resting upon the lack of market demand for the parcels and contingent upon continued economic instability or decline in the communities. As Figure 1 indicates, most of the community gardens are located in those census tracts with the lowest median income. Further examination of parcel data and census data also reveals that those census tracts also have the highest racial segregation and the highest concentration of vacant lots (KNIGGE 2006; KNIGGE \& CoPE forthcoming).

\subsection{Methods}

Reflecting the observation made by Lawson (1995) that multiple tools and scales of analysis are necessary to answer multilayered and complex questions, a mixed methods approach was selected for the main research project. Use was made of GIS mapping of census and parcel level land use data along with other ethnographic research methods, including participant observation, interviews and field inspections, digital photography, and survey questionnaires to iteratively and recursively explore the ways that community gardeners individually and collectively think about and use the material spaces of community gardens. The approach is referred to as grounded visualization (KNIGGE \& Cope 2006). This approach allowed initial identification of the location of responsibility for delivery of social services and care, previously provided by the State, with community members and community gardening organizations and led to the focus of this paper.

\section{Public space, citizenship, gender and geographies of welfare and care}

\subsection{Histories of public space and citizenship}

Public space and the public sphere have a history of exclusion and privilege, with women, working-class, racialized men and other groups being excluded from full access or participation. BoNDI and Domosh (1998) chronicle the development of a gendered separation of public and private spheres during the transition from feudalism in England in the late $15^{\text {th }}$ century through the transition to capitalism in the $19^{\text {th }}$ century in the United States when industrial employment 


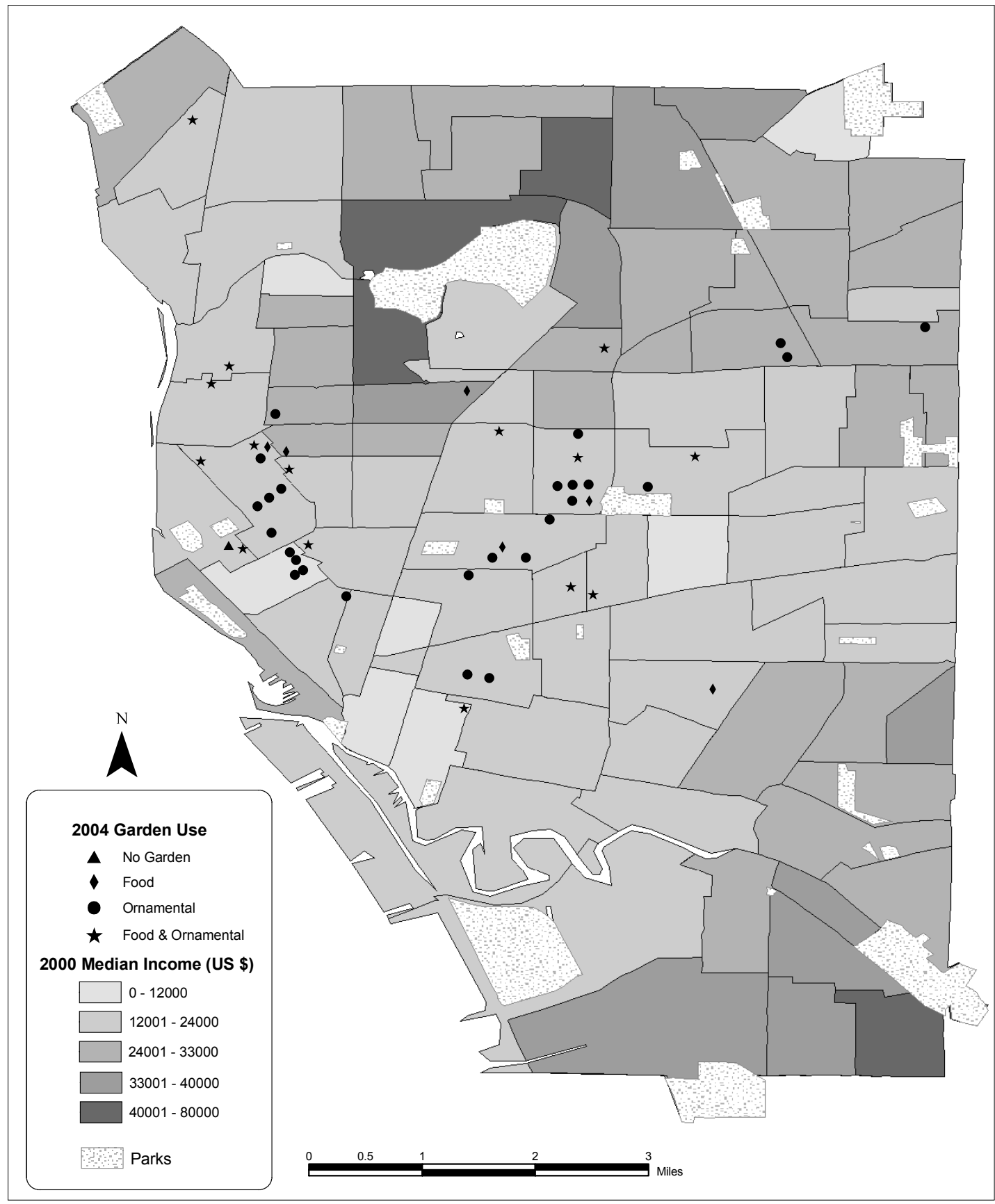

Fig. 1: Active community gardens 2004 and median income 2000 in Buffalo, NY Nutzung der Gemeinschaftsgärten 2004 und mittleres Einkommen 2000 in Buffalo, NY Usage des jardins communautaires en 2004 et revenu médian en 2000 à Buffalo, NY Source: KNIGGE (primary research, see KNIGGE 2006); median income: US census data, www. census.gov; cartography: L. KNIGGE 
took workers away from the home, changing spatial, gender and economic relations. The authors illustrate how the separation of spheres was inextricably bound up with gender and class relations as well as consumption, privilege and political participation and note that while the rhetoric of gender equality has become the norm, traces of the public/private dichotomy still linger today.

There is a close connection between public space and political participation in that public space does not simply exist; it is constantly defined and redefined, produced and reproduced through spatial and social practices. It is in public space that groups and individuals make their desires and needs known and represent themselves and their views to others and to the State with the aim of being seen and recognized as legitimate political actors (Mitchell 2003). However, it is debatable whether the simple provision of public space is sufficient to promote political discourse (Longan 2000; Mitchell 2003). Rather, according to Mitchell, a space is made public when taken by some group based upon a pressing need (2003: 35). Thus, public space is related to citizenship in that it is in public spaces that the rights of citizenship are enacted.

The definition of what constitutes citizenship, like public space, also has a long history of struggle and contestation with engagement in the public sphere limited to those who had rights of citizenship. Through concerted political efforts, women, Afro-Americans and other excluded groups have attained rights to citizenship and today in the United States there is an ideology of universal access to citizenship for all (except a few excluded groups: minors, prisoners and some immigrants) (Staeheli \& CoPE 1994). Regardless, many authors have also noted that rights and privileges of citizenship are not equally accessed by all due to continued informal barriers to participation based on class, race, gender, disability, sexuality, and other axes of difference (CHOUINARD 2004; GARBER \& Turner 1995; Kofman 1995; Kofman \& Peake 1990; Staeheli 1996; Staeheli \& Clarke 2003; Women and Geography Study Group 1997).

Citizenship is more than political rights, such as the right to vote. Small scale, everyday actions and activism at the level of the household and community also constitute political actions and thus are a way of enacting citizenship particularly for members of marginalized groups. In their discussion of women's rights to citizenship, StaeHeli and Cope (1994) note that due to their exclusion from public life, historically, women's political activities occurred at small scales in «private» places (women's homes, neighborhoods and communities). Today, much of women's local, community activ- ism continues to be concerned with the provision of care and services to the community. State restructuring and welfare reform have decreased or eliminated many state sponsored social services, while efforts to promote individual responsibility look to community and the private sector for the provision of these services. In this way, as suggested by STAEHELI, community has become

«a 〈space of betweeness linking public and private in ways that reflect political ideologies about responsibility for social welfare» (STAEHELI 2003: 818).

The growing of food and provision of community spaces and social services in vacant lot community gardens link public and private spheres and politicize the spaces of community gardens, as well as replacing formerly State provided social services to community members.

\subsection{Geographies of care and welfare}

«Care is society's work in the sense that care is absolutely central to our individual and collective survival. It is really quite striking how marginalized care is, when it is so central to every aspect of our lives. We all receive care, and throughout our lives many of us will also give care, under both joyful and sad circumstances. Marginalization of care is deeply political» (LAwson 2007: 5).

The extension of market relations and logics of efficiency and competition into all aspects of society have placed responsibility for care and service in the private sphere of homes and families (LAwson 2007). Feminist and critical theory examines the ways that care work has been privatized and devalued, the connections between women's political activism and the provision of care (STAEHEli 1996, 2003; StAeheli \& Clarke 2003; Staeheli \& Cope 1994; Staeheli \& Thompson 1997), and the impacts of state restructuring, privatization and welfare devolution on communities and individuals within the United States (TRUDEAU \& COPE 2003) with an increasing responsibility for care work falling upon women, ethnic minorities and immigrants (LAWSON 2007; Tronto 1993). In the 2006 Association of American Geographers Past President's Address entitled «Geographies of Care and Responsibility», VICTORIA LAWSON argues that welfare retrenchment, privatization, devolution and the extension of market relations into all factions of life has resulted in an emphasis on "greater efficiency and personal (rather than public) responsibility» which have both «made care a more pressing concern and simultaneously marginalized care from view» (LAWSON 2007: 1-2). The following section exemplifies this trend with case studies of three community gardening organizations that have expanded roles that include community service and the provision of care well beyond that typically associated with gardening. 


\section{Case studies and discussion}

The section describes three community garden projects that at the time of research were unique in their area in the extent to which their roles went beyond the provision of surplus vegetables and fruits to community members to include other forms of community service and care. The comparative base included over sixty community gardens included in the larger research study. The three community gardens have several elements in common. First, each garden is located on the East Side of Buffalo which has a predominantly African American population and the highest rates of poverty in the City of Buffalo. Second, each of the community organizations is led by a strong-willed, committed African American woman. Finally, each community organization also occupies a house located adjacent to the community garden site. The building is used for the provision of other forms of social services, such as youth programs, after-school programs, tutoring, coat drives, delivery of holiday gift baskets, refugee emergency and placement services.

The first garden, the We Care Neighborhood Block Club Community Garden (WCNBC) is a community and support center for area residents. A picnic table, barbeque grill and gazebo have been installed amongst the beds of flowers, vegetables and herbs for block club meetings and community events, including the fall harvest party. When referring to the services that the block club provides, Mrs. Targus, the community garden coordinator, frequently refers to her belief in God during conversations: «We don't have any money, but we get by on faith» and «We put God first; everyone has a connection to God» (personal interview Nov. 4, 2004). The house next door offers community services such as soup kitchen style lunches, facilities for the preparation of holiday food and gift baskets, as well as after school tutoring and programs for children.

The second garden, the International League of Muslim Women Community Garden (ILMW), was flourishing and expanding when visited in September of 2004. The surrounding neighborhood was marked by abandonment and urban decay with boarded up houses and vacant lots throughout the vicinity making the newly constructed arbor and picnic table built by local youth groups stand out against the aging infrastructure and urban decline. The community garden was already established when the house next door to the garden was donated to the organization as a community center after Mrs. Jones, the young-looking, seventy year old, African American garden coordinator expressed her desire to have a place for an office and community meetings. Besides maintaining the community garden, the organization provides refugee services, after school programs, tutoring, emergency and other placement services, as well as food and clothing «giveaways». The center also hosts an annual coat drive to provide winter clothing to low income families in collaboration with Journey's End Refugee Services.

Finally, the Community Action Information Center (CAIC) is another example of a group that extends community services well beyond gardening. This community organization maintains a cluster of community gardens and a community center that houses a food pantry, besides offering community services similar to those mentioned above in a neighborhood known for its gun violence and drug traffic. The CAIC gardens include an orchard, a patriotic garden, a community garden with allotment beds maintained by area senior citizens, and a memorial garden commemorating recent victims of gun violence (WILLIAMs 2006 and personal interview Aug. 31, 2004). City court judges frequently order convicted criminals to complete community service hours working in the community gardens that are supervised by Mrs. Johnson, the community garden coordinator, as part of their sentences.

Three important themes emerge from these case studies. First, the community organizations are clearly centers of care and support. The services that they provide replace social services and community support systems formerly provided by the State. These services, increasingly devolved or eliminated by welfare retrenchment, privatization, and devolution, fill pressing needs in the community and are critical to the survival of the communities and to many members of these communities. These community spaces become public in their occupation of the «space of betweeness» that links public and private. They reflect changing political ideologies that have resulted in the relocation of responsibility for social welfare into the private sphere, placing care in the community (STAEHELI 2003). Second, the roles of the African American women coordinators in the provision of social services and care to the community are consistent with the forms of local level activism that constitute political participation according to feminist theory. The spaces, made public through the provision of services by community gardening organizations, provide a space for the enactment of rights of citizenship by the women and members of other marginalized groups as they gain legitimacy as political actors through making their desires and needs known to the State and others. Third, the community organizations are not only providing services to community members and jobs and activities for youth programs, they are also providing services to the State through the oversight of community service work of criminals, as in the case of the CAIC community garden. 


\section{Conclusions}

The case studies highlight the effects of a dismantling of the welfare state and the devolution of responsibilities for social welfare to individuals and communities, enabled by both neoliberal and conservative forces. Here, such developments led to the use of public policy to locate responsibility for social welfare and care with community organizations in the private sphere, transferring the provision of care to the community. Situating community work within the larger project of state restructuring reveals the State's use of communities for the provision of social welfare services, physical care of vacant properties and even assistance in enforcing the criminal penal system. Thus, effects of larger structural processes, such as deindustrialization, privatization, and state restructuring could be directly felt by the residents of Buffalo in the palette of everyday problems they have to solve. Their lives within the context of the social, political and economic conditions are related to and cannot be separated from the larger global context.

\section{References}

Bondi, L. \& M. Domosh (1998): On the contours of public space: a tale of three women. - In: Antipode 30, 3: 270-289.

Brenner, N. \& N. Theodore (2002): Cities and the geographies of actually existing Neoliberalism. - In: Antipode 34, 3: 349-379.

Chouinard, V. (2004): Making feminist sense of the state of citizenship. - In: Staeheli, L., Kofman, E. \& L. Peake (eds): Mapping women, making politics: feminist perspectives on Political Geography. - London: Routledge. Cornell Cooperative Extension (2004): Vacant Land, Buildings and Facilities Asset Management Project Report, January 2004. - City of Buffalo, NY.

GARBER, J.A. \& R.S. TurNer (eds) (1995): Gender in urban research. - Urban Affairs Annual Review 42, Thousand Oaks, CA: Sage Publications.

Hanna, A.K. \& P. OH (2000): Rethinking urban poverty: a look at community gardens. - In: Bulletin of Science, Technology \& Society 20, 3: 207-216.

History OF BUfFAlo (2008): Bethlehem Steel Company in Lackawanna, NY. - http://ah.bfn.org/h/beth/ 02/16/2008. Hynes, H.P. (1996): A patch of Eden: America's innercity gardeners. - White River Junction, Vermont: Chelsea Green Publishing Company.

KNIGGE, L. (2006): Emerging public spaces in marginalized urban places: the political economy of community gardens in Buffalo, NY. - Unpublished PhD dissertation, Department of Geography, University at Buffalo, State University of New York.

KNIGGE, L. \& M. Cope (2006): Grounded visualization: integrating the analysis of qualitative and quantitative data through grounded theory and visualization. - In: Environment and Planning A 38, 11:2021-2037.
KNIGGe, L. \& M. Cope (forthcoming 2009): Grounded visualization and scale. A recursive analysis of community spaces. - In: CoPE, M. \& S. Elwood (eds): Qualitative GIS: a mixed methods approach. - London: Sage Publications.

Kofman, E. (1995): Citizenship for some but not for others: spaces of citizenship in contemporary Europe. - In: Political Geography 14, 2: 121-137.

Kofman, E. \& L. Peake (1990): Into the 1990s: a gendered agenda for political geography. - In: Political Geography Quarterly 9, 4:313-336.

LaChiusa, C. (2002): History of Buffalo. Bethlehem Steel Company in Lackawanna, NY: Timeline. - http:// ah.bfn.org/h/beth/ 05/26/2006.

LAWson, L.J. (2005): City bountiful: a century of community gardening in America. - Berkley and Los Angeles, CA: University of California Press.

LaWson, V. (1995): The politics of difference: examining the quantitative/qualitative dualism in post-structuralist feminist research. - In: Professional Geographer 47, 4: 459-457.

Lawson, V. (2007): Geographies of care and responsibility. - In: Annals of the Association of American Geographers 97, 1:1-11.

Leitner, H., Sheppard, E.S., Sziarto, K. \& A. MarinGANTI (2007): Contesting urban futures: decentering Neoliberalism. - In: LeITner, H., PeCK, J. \& E.S. ShePPARD (eds): Contesting Neoliberalism. - New York: Guildford Press: 1-25.

Longan, M. (2000): Community and place in cyberspace: the community networking movement in the United States. - Unpublished PhD dissertation, Department of Geography, University of Colorado.

Meyer, B. (2005): New capital budget allocated \$ 3.1 million for demolitions: control board head agrees with plan. - In: The Buffalo News, Buffalo, NY: B3, November 29.

Mitchell, D. (2003): The right to the city: social justice and the fight of public space. - In: New York: The Guilford Press.

SCHMELzKopf, K. (1995): Urban community gardens as contested space. - In: Geographical Review 85, 3: 364-381.

Schmelzkopf, K. (2002): Incommensurability, land use, and the right to space: community gardens in New York City. - In: Urban Geography 23, 4: 323343.

Smith, N. \& P. Williams (eds) (1986): Gentrification of the city. - Boston, London: Allen \& Unwin.

Staeheli, L.A. (1996): Publicity, privacy, and women's political action. - In: Environment and Planning D: Society and Space 14, 5: 601-619.

Staeheli, L.A. (2003): Women and the work of community. - In: Environment and Planning A 35, 5: 815831.

Staeheli, L.A. \& M. Brown (2003): Where has welfare gone? Introductory remarks on the geographies 
of care and welfare. - In: Environment and Planning A 35, 5: 771-777.

Staeheli, L.A. \& S.E. Clarke (2003): The new politics of citizenship: structuring participation by household, work, and identity. - In: Urban Geography 24, 3: 103-126.

Staeheli, L.A. \& M.S. Cope (1994): Empowering women's citizenship. - In: Political Geography 13, 5: 443-460. Staeheli, L.A. \& A. Thompson (1997): Citizenship, community, and struggles for public space. - In: Professional Geographer 49, 1: 28-38.

Tronto, J.C. (1993): Moral boundaries: a political argument for an ethic of care. - New York: Routledge.

Trudeau, D. \& M. Cope (2003): Labor and housing markets as public spaces: «personal responsibility» and the contradictions of welfare-reform policies. - In: Environment and Planning A 35, 5: 779-798.

WARNER, S.B. (1987): To dwell is to garden: a history of Boston's community gardens. - Boston: Northeastern Press.

WiLliams, D. (2006): Vandalism at gardens raises concern of community activist. - In: The Buffalo News, Buffalo, NY: B1, May 8.

Women and Geography Study Group (1997): Feminist geographies: explorations in diversity and difference. - Essex: Longman.

\begin{abstract}
Intersections between public and private: community gardens, community service and geographies of care in the US City of Buffalo, NY

This paper discusses issues of public space, citizenship, gender, and race in the light of public relocation of responsibility for social services and care to private communities due to the elimination, privatization or devolvement of such services by state restructuring and welfare reform. The presented case studies are taken from a larger study of community gardens in Buffalo, NY. This mixed methods study found connections between community organizations' commitment to community gardening and their involvement in the provision of social, youth, and emergency services, including after school programs, tutoring, refugee services, and winter coat drives. The paper concludes that the everyday lives of Buffalo's residents within the social, political and economic conditions cannot be separated from the effects of larger structural processes, such as deindustrialization, privatization, and state restructuring.
\end{abstract}

Keywords: grounded visualization, public space, gender, citizenship, state restructuring

Zusammenfassung: Schnittstellen zwischen öffentlich und privat: Gemeinschaftsgärten, Nachbarschaftshilfe und Geographien der Fürsorge in der amerikanischen Stadt Buffalo, NY

Dieser Artikel setzt sich kritisch mit den Konzepten Öffentlicher Raum,Bürgerrechte (citizenship), Gender und «Rasse» auseinander sowie mit den zunehmenden Absichten des Staates, öffentliche Dienst- und Fürsorgeleistungen, die im Zuge wohlfahrtsstaatlicher Reformen abgeschafft, abgebaut oder privatisiert wurden, durch Leistungen informeller Organisationen (communities) zu ersetzen. Die vorgestellten Argumente stützen sich auf eine breit angelegte Studie über Gemeinschaftsgärten (community gardens) in der Stadt Buffalo, NY, in der verschiedene quantitative und qualitative Methoden zur Anwendung gelangten (mixed methods study). Im Rahmen dieser Studie wurde festgestellt, dass viele Gemeinschaftsgarten-Organisationen sich nicht nur aufs «Gärtnern» beschränken, sondern sich auch aktiv an der Bereitstellung sozialer Dienstleistungen beteiligen. Dazu gehören unter anderem Freizeitprogramme für Kinder und Jugendliche, Aufgabenhilfen, Unterstützung von Flüchtlingen oder Kleidersammlungen. Der Artikel kommt zum Schluss, dass die sozialen, politischen und wirtschaftlichen Lebensumstände im Alltag der Wohnbevölkerung von Buffalo nicht getrennt von übergeordneten strukturellen Veränderungen wie Desindustrialisierungs-, Privatisierungs- und sozialstaatliche Restrukturierungsprozesse betrachtet werden können.

Schlüsselwörter: datenverankerte Visualisierung, öffentlicher Raum, Gender, Bürgerrechte, sozialstaatlicher Umbau

\section{Résumé: Intersections entre public et privé: jardins communautaires, relations de voisinage et géographie de l'assistance à Buffalo (NY, USA)}

Cet article traite de l'espace public, de la citoyenneté, du genre et des groupes ethniques dans un contexte nord-américain aujourd'hui caractérisé par un transfert de responsabilités des services sociaux en direction des acteurs privés. Aux Etats-Unis, ce transfert est essentiellement lié à la suppression, à la privatisation ou à la délégation de ces services qui sont intervenues consécutivement aux restructuration étatiques et aux réformes de l'assistance sociale. Les cas présentés proviennent d'une étude plus large conduite sur les jardins communautaires de Buffalo, dans l'Etat de New York. Cette étude, qui combine des éléments qualitatifs et quantitatifs, montre qu'il existe des liens entre l'engagement des communautés à s'occuper des jardins et leur implication dans la fourniture de services destinés aux jeunes, de services sociaux et de services d'urgence, y compris des programmes de garde d'enfants, de devoirs surveillés, d'aide aux réfugiés ou de récolte d'habits. L'article conclut que la vie quotidienne des résidents de Buffalo, dans les conditions sociales, politiques et économiques actuelles, ne peut être séparée des effets des processus structurels plus larges, comme la désindustrialisation, la privatisation et la restructuration de l'Etat. 
Mots-clés: visualisation inspirée de la Grounded Theory, espace public, genre, citoyenneté, restructuration de l'Etat

Dr. LaDona Knigge, Department of Geography and Planning, California State University, Chico, 507 Butte Hall, Chico, California 95929-0425, USA.

e-mail:1knigge@csuchico.edu

Manuskripteingang/received/manuscrit entré le 8.6.2008

Annahme zum Druck/accepted for publication/accepté pour l'impression: 27.2.2009 